\title{
Formulasi dan Uji Stabilitas Serbuk Perasan Jeruk Nipis (Citrus aurantifolia (Cristm.) Swingle) dengan Variasi Konsentrasi Carbopol 940
}

\author{
Dyera Forestryana* dan Shella Y. Rahman \\ Program Studi S1 Farmasi, Sekolah Tinggi Ilmu Kesehatan Borneo Lestari, Jl. Kelapa Sawit, Banjarbaru, \\ Kalimantan Selatan, Indonesia, 70732 \\ *email korespondensi : dyeraforestryana21@gmail.com \\ Received 10 Pebruary, Accepted 27 June 2020, Published 30 October 2020
}

\begin{abstract}
Abstrak: Jerawat umumnya disebabkan oleh Propionibacterium acnes yang dapat dihambat pertumbuhannya oleh air perasan jeruk nipis (Citrus aurantifolia (Cristm.) Swingle). Penelitian ini bertujuan untuk melakukan formulasi dan pengujian stabilitas gel antijerawat serbuk perasan jeruk nipis yang di freeze dried menggunakan variasi konsentrasi Carbopol 940 sebagai gelling agent. Tiga formula dengan variasi konsentrasi Carbopol 940 4, 6, dan 8\% diaplikasikan dalam pengujian stabilitas gel serbuk perasan jeruk nipis yang diperoleh secara liofilisasi. Pengujian stabilitas dilakukan sebelum dan sesudah freeze thaw terhadap sediaan yang meliputi organoleptis, homogenitas, viskositas, daya sebar, daya lekat, dan $\mathrm{pH}$. Analisis data dilakukan secara deskriptif terhadap pengujian organoleptis dan homogenitas, sedangkan viskositas, daya sebar, daya lekat dan $\mathrm{pH}$ dianalisis secara statistik (taraf kepercayaan 95\%). Hasil menunjukkan bahwa tidak terdapat perubahan sebelum dan sesudah freeze thaw pada pengujian homogenitas dan organoleptis. Daya sebar, daya lekat, dan viskositas gel seruk perasan jeruk nipis tidak mengalami perubahan yang bermakna untuk tiga formula sehingga dapat dinyatakan sediaan gel stabil sebelum dan sesudah freeze thaw. Namun, terdapat pengaruh yang bermakna terhadap penurunan $\mathrm{pH}$ setelah pengujian freeze thaw. Formula 3 (Carbopol 940 8\%) memiliki kestabilan yang baik pada pengujian sebelum dan sesudah freeze thaw.
\end{abstract}

Kata kunci: Anti jerawat; serbuk perasan jeruk nipis; gelling agent; Carbopol 940

\begin{abstract}
Formulation and stability study of lime juice powder (Citrus aurantifolia (cristm) Swingle.) gel using variation concentration of Carbopol 940. Acne is generally caused by the Propionibacterium acnes (P.acnes) which can be inhibited by lime (Citrus aurantifolia (Cristm.) Swingle) juice. This study was proposed to formulate and to investigate the stability of freeze-dried lime juice incorporated into gel formulation using Carbopol 940 as a gelling agent. Three formulations along with Carbopol 940 variation concentrations of 4, 6, and $8 \%$ for F1, F2 and F3, respectively were applied to investigate the stability study of freezedried lime juice. Stability testings were carried out before and after the freeze-thaw process e.g. organoleptic, homogeneity, $\mathrm{pH}$, viscosity, spreadability, and adhesion. Data analysis was carried out descriptively on organoleptic and homogeneity testing, meanwhile viscosity, spreadability, adhesion, and $\mathrm{pH}$ were analyzed statistically along with confidence level of $95 \%$. Results showed that there were no changes before and after the freeze-thaw cycles on the homogeneity and organoleptic testing. Spreadability, adhesion, and viscosity of freeze-dried lime juice gel were not significantly affected by the variation concentration of Carbopol and freeze thaw cycles recognized as a stable formulation. However, there was a significant effect on $\mathrm{pH}$ decreasing after freeze-thaw process. F3 (Carbopol 940 8\%) was the most stable formulation during freeze thaw cycling.
\end{abstract}


Keywords: Anti acne, Lime juice; Gelling agent; Carbopol 940

\section{Pendahuluan}

Jerawat menjadi permasalah besar bagi sebagian orang, karena jerawat dapat menurunkan rasa percaya diri dan merusak penampilan. Jerawat umumnya terjadi pada bagian kulit seperti di wajah, leher, dada, dan punggung. Beberapa faktor yang menyebabkan timbulnya jerawat adalah disebabkan oleh genetik, hormon, psikis, stress, makanan, bahan kimia, infeksi bakteri dan kebersihan (Manarisip, 2015). Infeksi bakteri menjadi penyebab umum timbulnya masalah jerawat, diantaranya adalah Propionibacterium acnes (P.acnes), Staphylococcus aureus (S.aureus), dan Staphylococcus epidermidis (S.epidermidis) (Meilina \& Aliya, 2018). Pengobatan jerawat selama ini dilakukan dengan menggunakan zat antibiotik. Namun, penggunaan antibiotik menyebabkan efek samping seperti iritasi dan penggunaan jangka panjang dapat menyebabkan resistensi (Madelina \& Sulistyaningsih, 2018). Oleh karena itu, diperlukan adanya terapi alternatif dari bahan alam yang berasal dari tumbuhan yang berpotensi tinggi sebagai antibakteri.

Upaya mengatasi resistensi terhadap antibiotik, masyarakat banyak menggunakan tanaman obat tradisional untuk menghilangkan jerawat. Salah satu tanaman yang terbukti secara empiris sebagai anti jerawat adalah jeruk nipis yaitu dengan cara di oleskan pada wajah yang digunakan oleh masyarakat Kabupaten Tanah Bumbu, Kalimantan Selatan (Radam dkk., 2016). Bagian jeruk nipis yang banyak dimanfaatkan dalam upaya menghilangkan jerawat adalah air perasannya. Air perasan jeruk nipis diketahui memiliki kandungan senyawa flavonoid yang dapat bekerja sebagai antibakteri melalui 3 mekanisme; menghambat sintesis asam nukleat pada bakteri, menghambat fungsi membran sel, dan menghambat metabolisme energi bakteri (Hendra dkk., 2011).

Selain flavanoid, perasan jeruk nipis segar mengandung beberapa komponen asam seperti asam sitrat $(6,15 \%)$, asam laktat $(0,09 \%)$, dan asam tartrat (Nour dkk., 2010). Beberapa senyawa asam organik ini berkontribusi terhadap aktivitas anti bakteri dari perasan jeruk nipis. Asam organik ini mampu menghambat pertumbuhan bakteri karena mempengaruhi $\mathrm{pH}$ di bawah pH optimum. Beberapa bakteri seperti Eschericia colli, Streptococcus haemolyticus, dan Staphylococcus aureus mampu dihampat oleh air perasan buah jeruk (Razak dkk., 2013). Srichan dkk. (2013) melaporkan bahwa jus buah jeruk nipis (Citrus aurantifolia (Cristm.) Swingle) mampu menghambat pertumbuhan bakteri $P$. acnes yang tergolong sangat kuat. Akan tetapi, jika perasan air jeruk nipis langsung diberikan untuk mengobati jerawat maka tidak akan efisien sehingga perlu pengembangan bentuk sediaan topikal untuk membantu dalam pengaplikasiannya. 
Menurut penelitian yang dilakukan oleh Srichan dkk. (2013), aktivitas antimikroba pada jus buah jeruk nipis (Citrus aurantifolia (Cristm.) Swingle) menunjukan bahwa perasan buah jeruk nipis dapat menghambat pertumbuhan bakteri $P$. acnes yang tergolong sangat kuat. Akan tetapi, jika perasan air jeruk nipis langsung diberikan untuk mengobati jerawat maka tidak akan efisien sehingga perlu pengembangan bentuk sediaan topikal untuk membantu dalam pengaplikasiannya.

Salah satu bentuk sediaan topikal yang dapat digunakan adalah gel, karena sediaan gel memiliki keuntungan karena memiliki kecepatan penetrasi yang lebih besar dibandingkan sediaan krim dan salep karena basis gel memiliki kandungan air paling tinggi diantara semua sediaan, sehingga meningkatkan hidrasi dari membran dan memudahkan penetrasi dari gel (Mulyana, 2016). Keuntungan sediaan gel adalah mudah dicuci dan memberikan rasa dingin di kulit. Kadar air yang tinggi pada sediaan gel, dapat mengurangi resiko timbulnya peradangan akibat adanya minyak pada pori-pori sehingga cocok digunakan sebagai sediaan dalam formulasi obat antijerawat. Karakteristik sediaan gel sangat tergantung dari bahan tambahan yang digunakan, utamanya adalah gelling agent seperti: poli asam akrilat (Carbopol 940). Polimer anionik umumnya tidak stabil pada terutama pada $\mathrm{pH}$ yang rendah, oleh karena itu kajian stabilitas dapat dilakukan pada polimer anionik realtif lebih nyata terutama jika menggunakan bahan aktif yang bersifat asam.

Jeruk memiliki sejuta manfaat yang dapat digunakan untuk kesehatan. Berbagai macam jenis jeruk dapat dimanfaatkan untuk pengobatan anti jerawat karena kandungannya sebagai anti bakteri. Jeruk nipis adalah salah satunya, beberapa formulasi buah jeruk nipis yang telah dilakukan untuk pengobatan anti jerawat diantaranya adalah formulasi perasan jeruk nipis dalam bentuk gel dan ekstrak kulit jeruk nipis. Penggunaan perasan jeruk nipis yang digunakan dalam pembuatan gel anti jerawat dalam bentuk perasan jeruk nipis dirasa tidak efektif dalam hal stabilitas, sehingga untuk meningkatkan stabilitas air perasan jeruk nipis tersebut dapat dilakukan dengan membuat serbuk kering perasan jeruk nipis dengan menggunakan freeze dryer. Formulasi gel perasan jeruk nipis yang diliofilisasi belum pernah dilaporkan sampai saaat ini. Penelitian ini bertujuan untuk memformulasikan serbuk perasan jeruk nipis yang diliofilisasi ke dalam bentuk sediaan gel dengan berbagai variasi konsentrasi Carbopol 940 dengan tujuan adalah untuk mengetahui pengaruh Carbopol 940 terhadap kestabilan fisik sediaan gel jeruk nipis yang meliputi organoleptik, daya sebar, $\mathrm{pH}$, viskositas, dan daya lekat.

\section{Bahan dan Metode}

\subsection{Bahan}

Serbuk perasan jeruk nipis diperoleh dari Kabupaten Tanah Bumbu, Kalimantan Selatan 
yang dikeringkan menggunakan freeze drying. Carbopol 940, trietanolamin (TEA), Tween 80, propilenglikol, dan metil paraben yang diperoleh dari Quadrant (Indonesia) serta air yang diperoleh dari supplier lokal. Bahan yang digunakan dalam penelitian ini adalah dalam derajat teknis.

\subsection{Penyiapan sampel dan freeze drying perasan jeruk nipis}

Buah jeruk nipis yang digunakan dengan usia 3 bulan dengan diameter 4-5 cm, berwarna hijau dan berbentuk bulat. Jeruk nipis yang sudah dikumpulkan lalu dicuci sampai bersih. Jeruk nipis diperas dengan menggunakan pemerasan manual untuk mendapatkan air perasannya. Setelah mendapatkan air perasan jeruk nipis kemudian disaring dengan kertas saring untuk memperoleh air perasan murni. Kemudian perasan jeruk nipis dikering bekukan untuk mendapatkan serbuk kering perasan jeruk nipis menggunakan alat freeze dryer. Proses freeze drying dilakukan dengan membekukan sari jeruk nipis pada suhu $-40^{\circ} \mathrm{C}$, kemudian perasan jeruk nipis yang telah beku tersebut dikeringkan dengan menggunakan pengeringan vakum. Hal ini memungkinkan pelarut beku dalam perasan jeruk nipis untuk menguap tanpa melalui fase cair, proses ini dikenal sebagai sublimasi. Untuk mempercepat proses sublimasi maka diberikan panas dengan suhu sekitar $100^{\circ} \mathrm{F}\left(38^{\circ} \mathrm{C}\right)$. Perasan jeruk nipis yang sudah kering ditimbang dan dihitung kadar air perasan jeruk nipis yang hilang.

\subsection{Pembuatan gel}

Formula gel antijerawat serbuk perasan jeruk nipis dapat dilihat pada Tabel 1. Sediaan gel serbuk perasan jeruk nipis dibuat kedalam 3 formula yaitu dengan konsentrasi Carbopol 940 4, 6, dan 8\% untuk F1, F2, dan F3. Pemilihan konsentrasi Carbopol 940 didasarkan pada hasil optimasi yang sebelumnya telah dilakukan. Pada rentang penggunaan Carbopol 940 adalah 0,5$2 \%$ tidak diperoleh viskositas yang diinginkan untuk sediaan gel karena bahan aktif yang bersifat asam, sehingga dilakukan peningkatan konsentrasi penggunaan Carbopol 940 menjadi 4, 6, dan $8 \%$. Hal ini disebabkan karena adanya pengaruh sari jeruk nipis yang bersifat asam sehingga menurunkan viskositas dari sediaan, selain itu pada konsentrasi rendah Carbopol 940 mengalami sineresis yang menyebabkan gel menjadi cair karena air tidak terikat kuat oleh komponen bahan yang ada.

Pada masing-masing formula, Carbopol 940 didispersikan dalam air panas hingga mengembang, kemudian masukkan TEA kedalam Carbopol 940 yang mengembang sambil diaduk hingga homogen. Larutkan metil paraben dengan propilenglikol, campurkan larutan metil paraben ke dalam Carbopol 940 yang mengembang diikuti dengan Tween 80, aduk hingga homogen. Zat aktif berupa serbuk jeruk nipis dilarutkan dalam propilenglikol sampai homogen, kemudian dimasukan kedalam basis gel yang telah terbentuk dan aduk hingga homogen. 


\subsection{Evaluasi sifat fisik gel}

\subsubsection{Uji organoleptis sediaan}

Evaluasi secara organoleptis yang dilakukan pada parameter bentuk, warna dan bau. Pengujian dilakukan setiap minggu selama 2 minggu masa penyimpanan.

\subsubsection{Uji daya sebar sediaan}

Sebanyak 0,5 g gel diletakkan pada bagian tengah petri dish kemudian ditutup dengan penutup yang telah ditimbang beratnya setelah gel menyebar selama 1 menit dan diukur diameter penyebarannya. Beban seberat $150 \mathrm{~g}$ ditambahkan selama 1 menit kemudian diameter sebarnya diukur (Sugihartini \& Lena, 2015). Penambahan beban berat setelah 1 menit ditujukan untuk memperoleh diameter yang cukup yang dipengaruhi oleh beban terhadap perubahan diameter sebar gel (Ismarani dkk., 2014). Diameter diukur dari dua sisi pengamatan dengan replikasi 3 kali. Pengujian dilakukan setiap minggu selama 2 minggu masa penyimpanan. Daya sebar (S) dihitung dengan menggunakan Persamaan 1 (Singh dkk., 2013) berdasarkan atas beban yang diberikan $(M ; \mathrm{g})$, lebar penyebaran yang dibentuk $(L ; \mathrm{cm})$, dan waktu $(T$, detik).

$$
S=\frac{M \times L}{T}
$$

Persamaan 1. Perhitungan daya sebar (S) berdasarkan atas beban yang diberikan $(M ; \mathrm{g})$, lebar penyebaran yang dibentuk $(L ; \mathrm{cm})$, dan waktu $(T$, detik).

\subsubsection{Uji daya lekat sediaan}

Sebanyak gel $(0,25 \mathrm{~g})$ diletakkan diantara 2 kaca objek pada alat uji daya lekat, kemudian beban seberat1 kg diletakkan selama 5 menit, dan beban dilepas. Beban (80 gram) dipasangkan pada alat uji daya lekat dan kemudian pengujian dimulai dengan melepas beban tersebut. Waktu yang dibutuhkan sampai kaca objek tersebut terlepas dicatat sebagai waktu lekat gel. Daya lekat pada sediaan topikal direkomendasikan lebih dari 4 detik (Sugihartini \& Lena, 2015). Pengujian daya lekat dilakukan sebanyak 3 kali replikasi dan diamati setiap minggu selama 2 minggu penyimpanan.

Tabel 1. Rancangan fomula gel serbuk liofilisasi perasan jeruk nipis dengan variasi konsentrasi Carbopol 940 sebagai gelling agent.

\begin{tabular}{lccc}
\hline \multicolumn{1}{c}{ Bahan } & FI $(\boldsymbol{\%}, \mathbf{b} / \mathbf{b})$ & $\mathbf{F 2}(\boldsymbol{\%}, \mathbf{b} / \mathbf{b})$ & $\mathbf{F 3}(\boldsymbol{\%}, \mathbf{b} / \mathbf{b})$ \\
\hline Serbuk perasan jeruk nipis & 20 & 20 & 20 \\
Carbopol 940 & 4 & 6 & 8 \\
Trietanolamin & 2 & 2 & 2 \\
Propilenglikol & 15 & 15 & 15 \\
Tween 80 & 3 & 3 & 3 \\
Metil paraben & 0,1 & 0,1 & 0,1 \\
Aquades & 55,9 & 53,9 & 51,9 \\
\hline
\end{tabular}




\subsubsection{Uji pH sediaan}

Evaluasi pH sediaan menggunakan pH meter (HI98107, Hanna, Indonesia). Alat pH meter dikalibrasi terlebih dahulu kemudian dicelupkan ke dalam sediaan gel (tip khusus semisolida). pH sediaan dapat diamati seperti yang tertera pada alat (Ismarani dkk., 2014). Pengujian daya lekat dilakukan sebanyak 3 kali replikasi dan diamati setiap minggu selama 2 minggu penyimpanan.

\subsubsection{Uji homogenitas}

Uji homogenitas dilakukan dengan cara mengoleskan sediaan gel pada kaca objek. Evaluasi homogentias ini ditunjukkan dengan sediaan harus menunjukan susunan yang homogen dan tidak ada butiran kasar (Astuti dkk., 2017).

\subsubsection{Uji viskositas}

Uji viskositas dilakukan dengan menggunakan viskometer Stromer (Tipe NDJ-5S, Gongyi Yuhua, China). Pengujian dilakukan dengan mencelupkan spindle no 4 yang sebelumnya telah di lakukan optimasi pemilihan spindle ke dalam $100 \mathrm{~g}$ sediaan dengan kecepatan $100 \mathrm{rpm}$. Viskositas sediaan dapat dilihat pada display layar. Nilai viskositas gel yang baik pada rentang 2000-4000 cps karena gel mampu menyebar dengan baik saat diaplikasikan dengan kekentalan tersebut (Purwati, 2016). Pengujian viskositas dilakukan replikasi sebanyak 3 kali. Pengujian dilakukan setiap minggu selama 2 minggu masa penyimpanannya.

\subsubsection{Uji stabilitas freeze thaw cycling}

Pengujian stabilitas sediaan gel yang meliputi organoleptis, homogenitas, viskositas, daya sebar, daya lekat, dan pH dilakukan sebanyak 6 siklus. Perubahan fisik gel serbuk perasan jeruk nipis diamati pada awal dan akhir siklus. Satu siklus gel dilakukan pada suhu $4^{\circ} \mathrm{C}$ selama 48 jam dan dilanjutkan pada suhu $27^{\circ} \mathrm{C}$ selama 48 jam (Warnida, 2016).

\subsection{Analisis data}

Uji organoleptis dan uji homogenitas dilakukan pengamatan secara deskripsi. Data hasil pengujian daya sebar, daya lekat, $\mathrm{pH}$ dan viskositas dianalisis secara statistic menggunakan One Way ANOVA dengan taraf kepercayaan 95\% $(p=0,05)$. Data berupa hasil sebelum dan sesudah pengujian stabilitas freeze thaw cycling untuk melihat pengaruh perbedaan konsentrasi. Penentuan formula terbaik didasarkan atas hasil pengujian stabilitas sebelum dan sesudah freeze thaw yang meliputi uji organoleptik, homogenitas, viskositas, daya sebar, daya lekat, dan $\mathrm{pH}$.

\section{Hasil dan Pembahasan}

Pembuatan gel dilakukan dengan cara pencampuran antara bahan aktif dengan komponen 
pembuat gel sampai homogen. Carbopol 940 digunakan sebagai gelling agent, TEA sebagai pembasa karena basis gel Carbopol 940 bersifat asam dengan kisaran pH 3 sehingga perlu ditambahkan pembasa agar dapat mengental dan membentuk massa gel yang baik (Dewi \& Saptarini, 2016). Propilenglikol berfungsi sebagai humektan, Tween 80 berfungsi sebagai pengemulsi beberapa senyawa minyak dalam serbuk perasan air jeruk, dan metil paraben sebagai bahan pengawet meningkatkan stabilitas dari perubahan kondisi sediaan gel oleh bakteri.

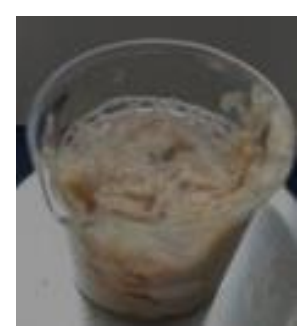

F1

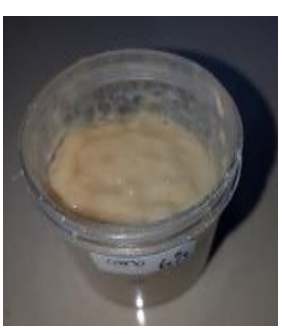

F2

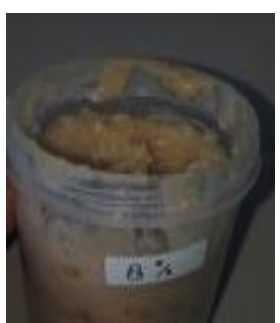

F3

Gambar 1. Penampilan tiga formula sediaan gel serbuk perasan jeruk nipis dengan variasi konsentrasi Carbopol 940 sebagai gelling agent.

Evaluasi uji yang dilakukan untuk sediaan adalah evaluasi fisik seperti evaluasi organoleptis, homogenitas, daya sebar, daya lekat, $\mathrm{pH}$, dan viskositas. Hal ini bertujuan untuk mengetahui kualitas sediaan berdasarkan parameter yang ada dengan tujuan untuk melihat kesesuaian sediaan dengan standar pengujian mutu sediaan gel. Uji stabilitas dengan freeze thaw cycling dilakukan untuk melihat kestabilan sediaan terhadap faktor suhu. Pengamatan dilakukan dengan mengamati perubahan fisik berupa organoleptis, daya sebar, daya lekat, $\mathrm{pH}$ dan viskositasnya sebelum dan seduah dilakukan freeze thaw cycling (Warnida dkk., 2016). Ketidak stabilan dapat muncul karena proses penyimpanan pada suhu ekstrim dibandingkan pada suhu ruang. Tampilan gel serbuk perasan jeruk nipis dapat dilihat pada

Tabel 2. Hasil uji organoleptis gel serbuk perasan jeruk nipis pada 3 formula dengan variasi konsentrasi Carbopol 940 sebagai gelling agent. +: agak cair; ++: agak kental; dan +++: kental.

\begin{tabular}{lcclc}
\hline Kondisi & Formula & Warna & Bau & Bentuk \\
\hline \multirow{3}{*}{ Sebelum Freeze Thaw } & 1 & Coklat & Khas jeruk nipis & +++ \\
& 2 & Coklat & Khas jeruk nipis & +++ \\
& 3 & Coklat & Khas jeruk nipis & +++ \\
\hline \multirow{3}{*}{ Sesudah Freeze Thaw } & 1 & Coklat & Khas jeruk nipis & + \\
& 2 & Coklat & Khas jeruk nipis & ++ \\
& 3 & Coklat & Khas jeruk nipis & ++ \\
\hline
\end{tabular}




\subsection{Uji organoleptis}

Pengujian organoleptis dilakukan terhadap tampilan sediaan meliputi bau, bentuk dan warna sediaan. Pengujian ini perlu dilakukan karena berkaitan dengan kenyamanan pemakaian sebagai sediaan topikal (Hanum \& Murrukmihadi, 2015). Hasil uji organoleptis dapat dilihat pada Tabel 2. Pengujian organoleptis dari ketiga formula ini memiliki karakteristik yang sama yaitu berwarna coklat, berbau khas dan berbentuk semi solid. Warna coklat yang dihasilkan pada sediaan karena adanya degradasi asam askorbat karena oksidasi jeruk nipis yang terpapar langsung dengan cahaya dan matahari sehingga terjadi pencoklatan pigmen karena kehilangan vitamin C. Pada pengujian stabilitas selama freeze thaw cycling secara organoleptis tidak terjadi perubahan signifikan pada warna, bau dan bentuk dari gel tersebut.

\subsection{Uji homogenitas}

Salah satu jaminan mutu dari suatu sediaan adalah homogenitas bahan yang merupakan evaluasi penting pada formulasi sediaan farmasetik untuk mengetahui ketercampuran suatu bahan dalam formula (Hanum \& Murrukmihadi, 2015). Pengujian homogenitas bertujuan untuk mengkarakterisasi homogenitas gel dengan melihat ketercampuran antar bahan. Hasil uji homogenitas dapat dilihat pada Tabel 3.

Tabel 3. Hasil uji homogenitas gel serbuk perasan jeruk nipis pada 3 formula dengan variasi konsentrasi Carbopol 940 sebagai gelling agent.

\begin{tabular}{lcc}
\hline Kondisi & Formula & Keterangan \\
\hline Sebelum Freeze Thaw & 1 & Homogen \\
& 2 & Tidak homogen \\
Sesudah Freeze Thaw & 3 & Tidak homogen \\
& 1 & Homogen \\
& 2 & Tidak homogen \\
& 3 & Tidak homogen \\
\hline
\end{tabular}

Pengujian homogenitas ini bersifat visual dan subyektif dengan parameter ada tidak butiran kasar dalam sediaan. Berdasarkan hasil uji homogenitas yang telah dilakukan menunjukan bahwa F1 dinyatakan homogen, F2 dan F3 dinyatakan tidak homogen. Hal ini ditunjukkan dengan adanya butiran kasar.

\subsection{Uji viskositas}

Viskositas berkaitan erat dengan pengujian daya sebar, semakin tinggi nilai viskositas maka semakin rendah kemampuan menyebar dari suatu sediaan. Uji viskositas dilakukan untuk mengetahui daya alir atau kekentalan suatu sediaan. Dari hasil pengujian ketiga sediaan memiliki nilai viskositas yang baik (Gambar 2), dimana dalam pengujiannya gel memenuhi ketentuan 
viskositas yang baik dengan rentang viskositas berkisar antara $2.000-4.000$ cps Hal ini menandakan bahwa formula sediaan gel yang dihasilkan memenuhi persyaratan (Purwati, 2016).

Hasil pengujian viskositas sediaan yang paling rendah terdapat pada formula 1 dengan konsentrasi Carbopol 940 yang digunakan adalah 4\%. Sedangkan nilai viskositas tertinggi terdapat pada formula 2 dan 3 dengan konsentrasi Carbopol 940 yang digunakan adalah $6 \%$ dan 8\%. Hal ini menunjukan bahwa semakin tinggi konsentrasi Carbopol 940 yang digunakan maka viskositas sediaan gel akan semakin meningkat (Rowe dkk., 2009).

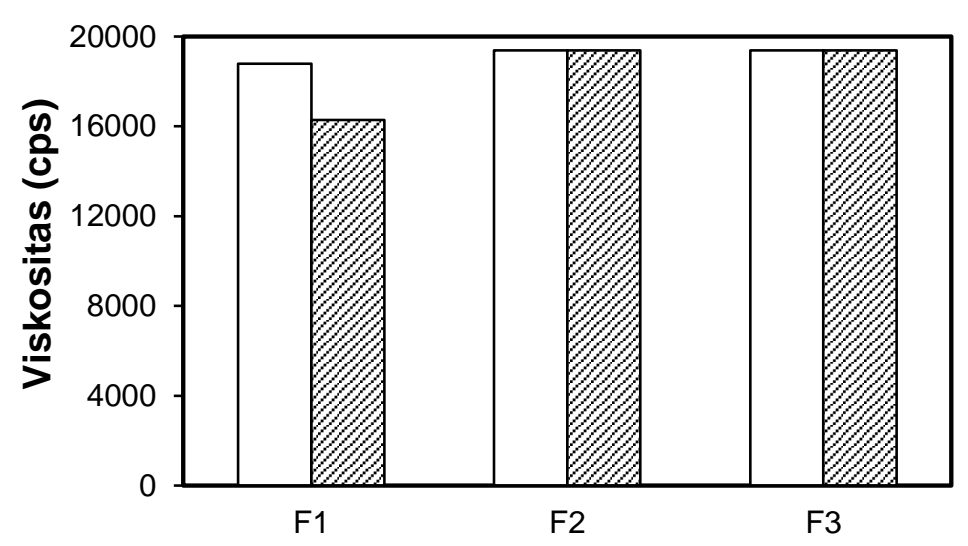

Gambar 2. Grafik hasil uji viskositas gel serbukperasan jeruk nipis sebelum freeze thaw cycling ( $\square$ ) dan sesudah freeze thaw cycling ( $\square$ ) menggunakan variasi konsentrasi Carbopol 940 4\% (F1), 6\% (F2), dan 8\% (F3).

Setelah perlakuan uji freeze thaw, menunjukan adanya penurunan viskositas pada F1 sedangkan pada F2 dan F3 viskositasnya tetap. Hal ini disebabkan karena konsentrasi rendah Carbopol 940 pada F1. Penggunaan Carbopol 940 dengan konsentrasi rendah menyebabkan penurunan robustness sediaan gel yang disebabkan karena sedikitnya struktur koloid tiga dimensi yang terbentuk, sehingga daya serap air menurun dalam waktu yang lama pada penyimpanan suhu rendah. Stabilitas pada proses penyimpanan dipengaruhi oleh rendahnya konsentrasi Carbopol 940 sehingga tidak stabil dalam penyimpanan, sedangkan konsentrasi Carbopol 940 yang tinggi cenderung memiliki stabilas yang baik selama pengujian (Sayuti, 2015). Polimer Carbopol 940 akan membentuk cross linking pada struktur koloid sehingga meningkatkan viskositas karena matriks tiga dimensi yang terbentuk (Suhaime dkk., 2012). Tingkat kekentalan suatu sediaan berbanding lurus dengan derajat cross-linking pada suatu polimer. Hal ini sesuai dengan yang terjadi pada F2 dan F3 memiliki nilai viskositas yang tetap stabil selama proses freeze thaw cycling. Hasil uji analisis data menunjukan bahwa tidak ada pengaruh secara signifikan, sebelum dan sesudah freeze thaw cycling tidak mempengaruhi stabilitas gel $(p>0,05)$. Nilai viskositas pada formula 1, 2 dan 3 selama penyimpanan tetap stabil. 


\subsection{Uji daya lekat}

Pengujian daya lekat ditujukan untuk mengetahui waktu kemampuan gel menempelnya pada kulit serta mengetahui pengaruh konsentrasi gelling agent (Carbopol 940) pada kekuatan melekat. Hasil uji daya lekat dapat dilihat pada Gambar 3. Berdasarkan hasil uji daya lekat didapatkan bahwa dari tiga formula, maka F3 memiliki rata-rata daya lekat paling lama yaitu 88 detik, pada F2 memiliki daya lekat 81 detik sedangkan F1 memiliki daya lekat 67 detik. Daya lekat sediaan topikal yang baik telah dilaporkan jika lebih dari 4 detik (Pratimasari dkk., 2015), sehingga sediaan gel serbuk perasan jeruk nipi tersebut memenuhi persyaratan daya lekat, semakin besar nilai viskositas menyebabkan peningkatan daya lekatnya sediaan gel.

Setelah dilakukan uji stabilitas freeze thaw cycling selama 6 siklus (48 jam), daya lekat mengalami kenaikan karena viskositas mengalami kenaikan. Pada F1 rata-rata daya lekat yang diperoleh adalah 84 detik, daya lekat pada F2 adalah 85 detik sedangkan daya lekat mengalami penurunan pada F3 adalah 85 detik. Hasil menunjukan bahwa tidak ada pengaruh secara signifikan sebelum dan sesudah freeze thaw cycling yang mempengaruhi stabilitas gel $(p>0,05)$.

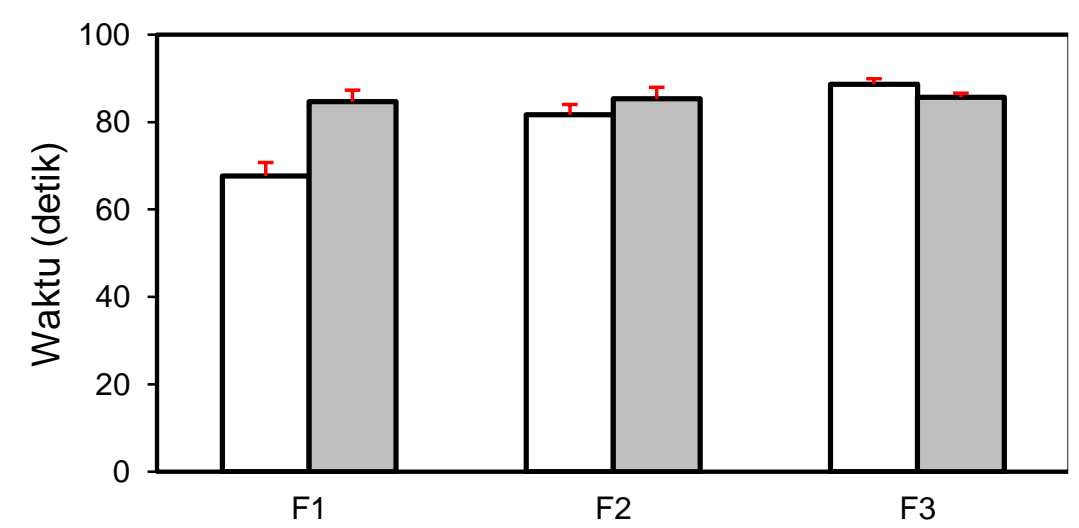

Gambar 3. Grafik hasil uji daya lekat gel serbuk perasan jeruk nipis sebelum freeze thaw cycling $(\square)$ dan sesudah freeze thaw cycling $(\square)$ menggunakan variasi konsentrasi Carbopol 940 4\% (F1), 6\% (F2), dan 8\% (F3).

\subsection{Uji daya sebar}

Daya sebar menunjukkan kemudahan sediaan gel serbuk perasan jeruk nipis mudah dioleskan. Semakin tinggi konsentrasi Carbopol 940 telah dilaporkan terjadinya penurunan daya sebar sediaan gel (Mursyid, 2017). Penurunan daya sebar disebabkan karena peningkatan viskositas dengan meningkatnya konsentrasi Carbopol 940. Hasil evaluasi daya sebar sediaan gel serbuk perasan jeruk nipis disajikan pada Gambar 4. Berdasarkan hasil uji daya sebar F1 memiliki daya sebar rata-rata 10,83 g.cm/detik, F2 memiliki daya sebar rata-rata 8,42 g.cm/detik dan F3 memiliki daya sebar 5,60 g.cm/detik. Daya sebar memiliki pengaruh di dalam pelepasan obat karena semakin luas sediaan menyebar sebanding dengan peningkatan 
koefisien difusi dan meningkatkan pelepasan dan difusi obat.

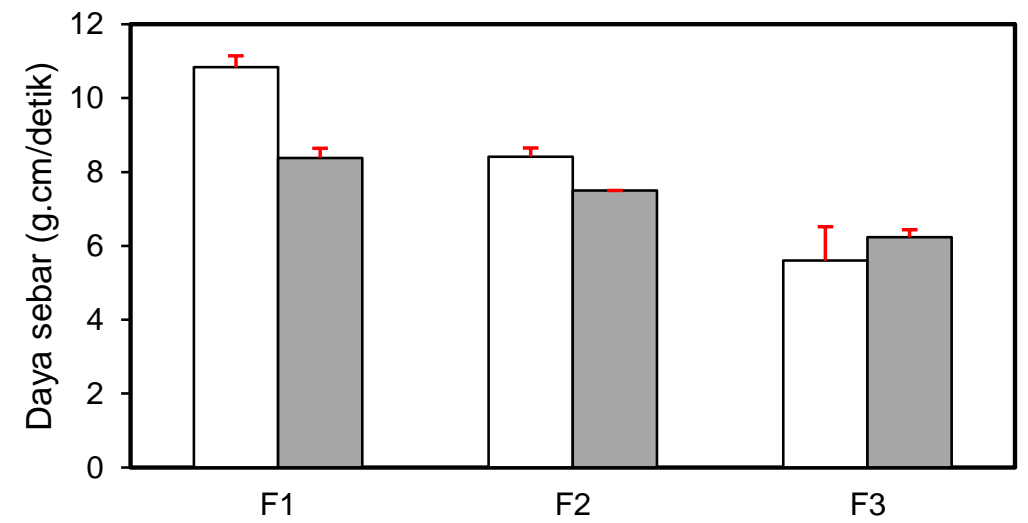

Gambar 4. Grafik hasil uji daya sebar gel serbuk perasan jeruk nipis sebelum freeze thaw cycling $(\square)$ dan sesudah freeze thaw cycling $(\square)$ menggunakan variasi konsentrasi Carbopol 940 4\% (F1), 6\% (F2), dan 8\% (F3).

Hasil pengukuran daya sebar ketiga formula selama freeze thaw cycling menunjukan adanya perubahan daya sebar pada sediaan. Perubahan konsistensi gel meyebabkan perubahan ketahanan dari struktur gel sehingga mempengaruhi nilai daya sebar sediaan gel serbuk perasan jeruk nipis. Peningkatan perubahan viskositas dapat menyebabkan semakin tinggi nilai perubahan pada penurunan daya sebar (Sayuti, 2015). Akan tetapi, evaluasi stabilitas menunjukan bahwa tidak ada pengaruh secara signifikan sebelum dan sesudah freeze thaw cyling $(p>0,05)$.

\subsection{Uji pH}

Uji $\mathrm{pH}$ ditujukan untuk mengevaluasi $\mathrm{pH}$ sediaan agar dapat disesuaikan dengan $\mathrm{pH}$ kulit sehingga tidak mengiritasi kulit. Perubahan $\mathrm{pH}$ juga diamati sebelum dan sesudah freeze thaw cycling. pH yang baik untuk kulit yaitu 4-6,5 (Ainaro dkk., 2015). Hasil uji pH dapat dilihat pada Gambar 5. Hasil pengujian $\mathrm{pH}$ terhadap ketiga formula yang diuji masing-masing memiliki pH yaitu pada F1 yaitu 4,26, formula 2 sebesar 4,43 sedangkan pada formula 3 sebesar 4,83. Hal ini menunjukan bahwa $\mathrm{pH}$ yang dihasilkan pada sediaan gel serbuk perasan jeruk nipis telah memenuhi standar. Penggunaan Carbopol 940 memiliki pH asam pada bentuk dispersinya dalam air, sehingga diberikan TEA untuk menetralkannya agar stabilitas sediaan gel dapat terjaga. Penggunaan serbuk perasan jeruk nipis mampu berkontribusi terhadap penurunan $\mathrm{pH}$ sehingga memiliki kecenderungan yang tinggi untuk berubah stabilitasnya pada parameter $\mathrm{pH}$. 


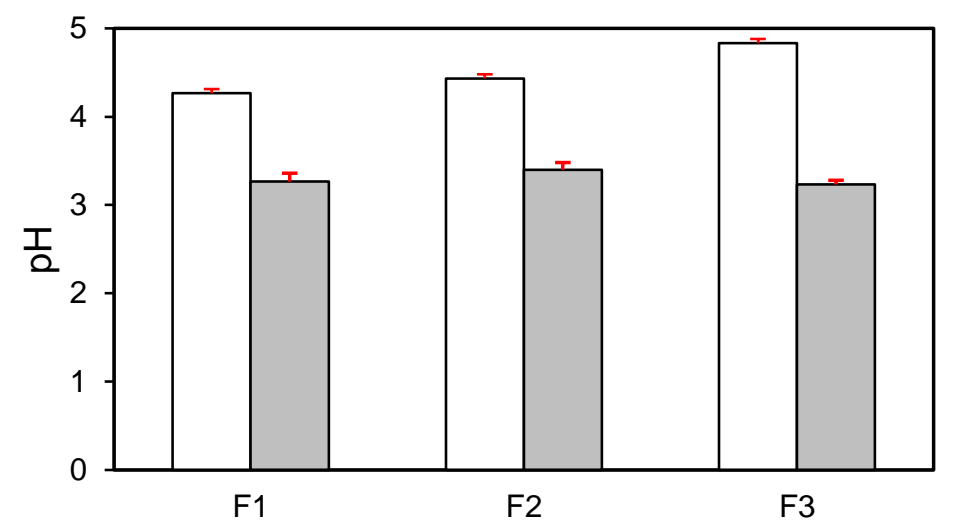

Gambar 5. Grafik hasil uji pH gel serbuk perasan jeruk nipis sebelum freeze thaw cycling ( $\square$ ) dan sesudah freeze thaw cycling $(\square)$ menggunakan variasi konsentrasi Carbopol $9404 \%$ (F1), 6\% (F2), dan 8\% (F3).

Hasil analisis menunjukan bahwa ada pengaruh secara signifikan sebelum dan sesudah freeze thaw cyling yang mempengaruhi stabilitas gel $(p<0,05)$. Hasil pengujian $\mathrm{pH}$ selama freeze thaw cycling, sediaan gel serbuk perasan jeruk nipis mengalami penurunan $\mathrm{pH}$, disebabkan karena sifat jeruk nipis yang bersifat asam dapat mempengaruhi $\mathrm{pH}$ sediaan menjadi asam. Menurunnya nilai $\mathrm{pH}$ sediaan berbanding lurus dengan konsentrasi serbuk jeruk nipis yang digunakan karena berkaitan dengan kandungan asam yang dikandung oleh serbuk perasan jeruk nipis. Jeruk nipis mengandung asam-asam organik berupa asam sitrat sebesar 7-7,5\% (Imanuela dkk., 2012).

\section{Kesimpulan}

Perbedaan konsentrasi gelling agent dapat mempengaruhi sifat fisik gel berupa daya lekat, daya sebar, dan viskositas sebelum dan sesudah uji stabilitas freeze thaw cycling. Semakin tinggi konsentrasi gelling agent, maka akan meningkatkan viskositas, daya lekat dan menurunkan daya sebar. Proses freeze thaw memberikan kontribusi terhadap stabilitas $\mathrm{pH}$ sediaan gel serbuk perasan jeruk nipis. Berdasarkan hasil pengujian stabilitas sebelum dan sesudah freeze thaw, diperoleh formula optimum sediaan gel serbuk perasan jeruk nipis pada F3 karena memiliki kestabilan yang lebih baik secara organoleptis, daya sebar, daya lekat, pH dan viskositas terhadap pengaruh suhu.

\section{Deklarasi Konflik Kepentingan}

Semua penulis menyatakan tidak ada konflik kepentingan terhadap naskah ini. 


\section{Daftar Pustaka}

Ainaro, E. P., Gadri, A., Priani, S. E. (2015). Formulasi sediaan masker gel peel- off mengandung lendir bakteri bekicot (Achatina fulica Bowdich) sebagai pelembab kulit. Prosiding Penelitian SPeSIA Unisba, pp. 86-95, Bandung: Unisba.

Astuti, P.A., Patihul, H., Kusdi, H. (2017). Formulasi dan uji stabilitas fisik sediaan gel antiseptik tangan minyak atsiri bunga lavender (Lavandula angustifolia Miller). Farmaka Suplemen, 15(1), pp. 176-184.

Dewi, C. C., \& Saptarini, N. M. (2016). Hidroksi propil metil selulosa dan karbomer serta sifat fisikokimianya sebagai gelling agent. Farmaka, 14(3), pp. 1-10.

Hanum, P. A., \& Murrukmihadi, M. (2015). Pengaruh variasi kadar gelling agent HPMC Terhadap sifat fisik dan aktivitas antibakteri sediaan gel ekstrak etanolik daun kemangi. Majalah Farmaseutik. 11 (2), pp. 307-315.

Hendra, R., Ahmad, S., Sukari, A, Shukor, M.Y., Oskoueian, E. (2011). Flavonoids Analyses and Antimicrobial Activity of Various Parts of Phaleria macrocarpa (Scheff.) Boerl Fruit. Int. J. Mol. Sci., 12, pp. 3422-3431.

Imanuela, M., Sulistyawati dan M. Ansori. 2012. Penggunaan asam sitrat dan natrium bikarbonat dalam minuman jeruk nipis berkarbonasi. Food Science Culunary Education Journal, 1(1), pp. 27-30.

Ismarani, D. Pratiwi, L. Kusharyanti. (2014). Formulasi gel pacar air (Impatient balsamina Linn) terhadap Propionibacterium acnes dan Staphylococcus epidermis. PharmSci Res., 1(1), pp. 30-45.

Madelina, W., Sulistiyaningsih. (2018). Review: Resistensi antibiotik pada terapi pengobatan jerawat. Farmaka, 16(2), pp. 105-117.

Manarisip, C.K. (2015). Hubungan stres dengan kejadian Acne vulgaris pada mahasiswa semester V (Lima) Program Studi Ilmu Keperawatan Fakultas Kedokteran Universal Sam Ratulangi Manado. E-Journal Keperawatan, 3(1), pp. 1-6.

Meilina, N.E., Aliya, N. H. (2018). Review Artikel: Aktivitas antibakteri ekstrak kulit buah manggis (Garnicia mangostana L.) terhadap bakteri penyebab jerawat. Farmaka, 16(2), pp. 322-328.

Mulyana, S. (2016). Pengaruh Propilen Glikol terhadap Penetrasi Gel Hesperidin Secara In Vitro. Skripsi. Program Studi Farmasi, Fakultas Kedokteran, Universitas Tanjungpura, Pontianak.

Mursyid, A. M. (2017). Evaluasi Stabilitas Fisik dan Profil Difusi Sediaan Gel (Minyak Zaitun). Jurnal Fitofarmaka Indonesia, 4(1), pp. 205-2011.

Nour, V. I., Trandafir, I., Ionica, M. E. (2010). HPLC organic acid analysis in different citrus juice under reversed phase conditions. Agroboth. Cluj, 38(1), pp. 44-48.

Pratimasari, D., Nining S., Tedjo, Y. (2015). Daya iritasi dan sifat fisik sediaan salep minyak atsiri bunga cengkeh (Syzigium aromaticum) pada basis hidrokarbon. Majalah Farmaseutik, 12 (1), pp. 372-376.

Purwati, V. (2016). Aktivitas antioksidan dan evuluasi fisik sediaan masker gel peel off dari ekstrak kulit terung ungu (Salonum melongena L.). Indonesia Natural Research Pharmaceutikal Journal, 1(2), pp. 10-21.

Radam, R., Soendjoto, M.A., Prihatiningtyas, E. (2016). Pemanfaatan Tumbuhan Yang Berkhasiat Obat Oleh Masyarakat Di kabupaten Tanah Bumbu, Kalimantan Selatan. Potensi, Peluang dan Tantangan Pengelolaan Lingkungan Lahan Basah Secara Berkelanjutan:Prosiding Seminar Nasional Lahan Basah, Jilid 2 (pp 486-492). Lembaga Penelitian dan Pengabdian kepada Masyarakat, Universitas Lambung Mangkurat Banjarbaru. 
Razak, A., Djamal, A., Revilla, G. (2013). Uji Daya Hambat Air Perasan Buah Jeruk Nipis (Citrus aurantifolia s.) Terhadap Pertumbuhan Bakteri Staphylococcus Aureus Secara In Vitro. Jurnal Kesehatan Andalas, 2(1), pp. 5-8.

Rowe, R., Sheskey, C. P. J., \& Quinn, M. E. (2009). Handbook of Pharmaceutical care Excipient $6^{\text {th }}$ Ed. Pharmaceutical Press, London.

Sayuti, N.A. (2015). Formulasi dan uji stabilitas fisik sediaan gel ekstrak daun ketepeng Cina (Cassia alata L.). Jurnal Kefarmasian Indonesia, 5(2), pp. 74-82.

Singh, V. K., Singh, P. K., Sharma, P. K., Srivastava, P. K., Mishra, A. (2013). Formulation and evaluation of topical gel of acelofenac containing piparine. Indo Am J Pharm Res, 3 (7), pp. 5266-5280.

Srichan, T., Phorom, Y., , and Phaechamud, T. (2013). Antimicrobial Activity of Citrus spp Fruit Juices. Thai Pharmaceutical and Health Science Journal, 8(1): pp. 7-11.

Sugihartini, N., Lena, M. (2015). Formula Gel Ekstrak Etanol Kulit Buah Manggis (Garcinia Mangostana L.) Dengan Variasi Gelling Agent Sebagai Sediaan Luka Bakar. Pharmaciana, 5(1), pp. 43-52.

Suhaime, I.H.B., Tripathy, M., Mohamed, M.S., Majeed, A.B.A. (2012). The pharmaceutical applications of carbomer. Asian Journal of Pharmaceutical Sciences and Research, 2 (2), pp. 1-12.

Warnida, H., Juliannor, A., Sukawati, Y. (2016). Formulasi pasta gigi gel ekstrak etanol bawang dayak (Eleutherine bulbosa (Mill.) Urb.). Jurnal Sains Farmasi dan Klinis, 3(1), pp. 4249.

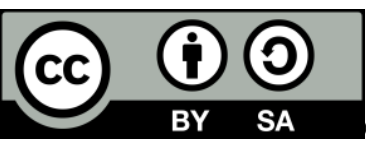

2020 by the authors. Submitted for possible open access publication under the terms and conditions of the Creative Commons Attribution-ShareAlike 4.0 International (CC BY-SA 4.0) license (https://creativecommons.org/licenses/by-sa/4.0/). 